\title{
THE IMPLEMENTATION OF CORPORATE SOCIAL RESPONSIBILITY IN INDONESIANN BANKING INDUSTRY
}

\author{
DOI: 10.17261/Pressacademia.2019.1040 \\ JBEF- V.8-ISS.2-2019(2)-p.93-100 \\ Lindiawati \\ STIE Perbanas, Management Department, Surabaya, Indonesian \\ lindi@perbanas.ac.id, ORCID: https://orcid.org/0000-0003-4498-3208
}

Date Received: February 24, 2019

Date Accepted: April 25, 2019

To cite this document

Lindiawati (2019). The implementation of corporate social responsibility in Indonesian banking industry? Journal of Business, Economics and Finance (JBEF), V.8(2), p.93-100.

Permemant link to this document: http://doi.org/10.17261/Pressacademia.2019.1040

Copyright: Published by PressAcademia and limited licenced re-use rights only.

\begin{abstract}
Purpose- The purpose of this study is to evaluate the implementation of Corporate Social Responsibility (CSR) programs in Indonesiann banking industry especially banks categorized under BUKU 3 which means the banks having the capital range of 5-30 trillions.

Methodology- The analysis refers to the classification of CSR programs based on the category falling into environment, health, education, disaster, donation, employee, and product; and on CSR benefit or impact covering philanthrophy, promotion, business impact, and mindsetchange. Using content analysis and census sampling technique, data were explored 2015-2018 annual reports of 15 member banks

Findings- The result showed that based on the Category classification, the banks' CSR programs mostly were delivered to education, environment, and employees dominated taking 26\%, 22\%, 20\% successively. The implication is that while those three categories are well supported, banks quite equally care of internal wealth. Anyhow, based on Benefit, the result showed that mindset change effect took only $7 \%$ leading to the implication that the level of CSR in banking industry is still low and this also refers that the community condition and country development are still relatively low.

Conclusion- The banks having good rank in the kind of CSR sectors are relatively also have good rank in CSR impacts which show good level in the CSR impact of promotion and business impact. By CSR sectors, the high coverage successively are education sector, environment, employees and donations. The impact of CSR dedicated for internal and external party are in balance. Specifically, by CSR impact, CSR is aware of promoting and caring for business impacts for the bank business sustainability. Anyhow, Indonesian banking industry show very weak role in helping change people mind set for better human quality
\end{abstract}

Keywords: Corporate social responsibility, CSR Category, CSR Benefit, stakeolders, company image JEL Codes: C52, M14, 018

\section{INTRODUCTION}

All companies including banks must be aware of implementing Corporate Social Responsibility (CSR) (Krasodomska, 2015). In Indonesian, implementing CSR has been an obligation for those of public limited companies as set by the regulations of CSR namely Act No. 40/2007 on Limited Liability Companies, Act No. 25/2007 on Investment, Act No. 47/2012 on Social Responsibility and Environment of Limited Company, Act No. 32/2009 on the Protection and Environmental Management, Act No. 22/2001 on Oil and Gas, Minister Regulation No. PER-05 / MBU / 2007 on Partnership Program of State-owned Enterprises with Small and Community Development Program. CSR bank is an important aspect that should be designed appropriately based on the benefit for the stakeholders (benefits of CSR for customer). Therefore banks need to explore positive aspects that reflect the responsibilities of banks both internal and externally (Kansal, Joshi, \& Batra, 2014; Khan, 2010; Virvilaite \& Daubaraite, 2011; Yeo \& Youssef, 2010). The Positive aspects strategically developed should be communicated to the public in an effort to enhance the positive image of public to the bank (Virvilaite \& Daubaraite, 2011). CSR benefits for bank stakeholders 
should receive attention because it will contribute to the bank's business continuity (Garriga \& Mele, 2004; Pérez \& Del Bosque, 2015). Therefore, making CSR as the obligation referred to regulation, needs to be designed in order to effectively and efficiently beneficial for the public and the banks.

The effects of CSR still varies from the simple one in which CSR is viewed as corporate phillantrophy, then viewed as an attempt to support societal marketing, and the utmost level of effect is viewed as a means of changing way of thinking (Solihin, 2009). There are three main reasons of why companies implement corporate social responsibility (CSR), which are to show concern for the people and environment of the company; as an activity of interaction with stakeholders; as well as a manifestation of the desire of companies to enable the continuity of businesses (Pérez \& Lopez-Gutierrez, 2017). This notion refers to the assumption that the corporation is an instrument for wealth creation looking at the economic aspect of the interactions between business and society. So any supposed social activity is accepted if, and only if, it is consistent with wealth creation (Garriga \& Mele, 2004). These considerations must flow down to changes in public behavior positively to the bank, especially customers and potential customers. Customers' behavior, as the result of CSR, show trust to the bank. This is very important since the bank's business is essentially based on customers trust (Krasodomska, 2015). Considering all of these reasons, it is important to know what CSR program the banks have been implementing, so the mapping of programs viewed from the perspectives of Category and Benefit may show what have been happening and what can be designed in the future.

\section{LITERATURE REVIEW}

\subsection{Corporate Social Responsibility and Company's Image}

CSR is a construct that develops the relationship between the company and its environment (Krasodomska, 2015). More specifically, CSR is defined as all activities of the company which shows programs that involve the community, the environment and the interaction between companies with all stakeholders (Jain, R., \& Winner, 2016; Kansal et al., 2014). This notion refers to the assumption that the corporation is an instrument for wealth creation looking at the economic aspect of the interactions between business and society. So any supposed social activity is accepted if, and only if, it is consistent with wealth creation. This group of theories could be call instrumental theories because they understand CSR as a mere means to the end of profit

To counter the challenges of its business, the company must conduct a review of the activities that need to be done by involving the community and its stakeholders. Since stakeholders are not only those of external parties but also the internal one, CSR is effective in improving employee well-being and improving employee retention rate. Referring to its stakeholders, CSR has dimensions namely customer, employee, shareholder, government and the general public who each has the demands on the company's CSR. Thus, companies should be able to map where the stakeholders are in the priority implementation of Companies CSR that it can give positive impacts for both companies and for stakeholders (Pérez \& Del Bosque, 2015).

Considering CSR into the strategic planning of a company will improve its performance, then it will enhance corporate image and reputation (Pérez \& Del Bosque, 2015; Virvilaite \& Daubaraite, 2011). Bank reputation must be maintained by setting up neccesary CSR programs involving activities leading to social welfare (Chaudhri, 2016). The activities are published through CSR report that is attempted to communicate the company's care to society. Some research studies explained that banks with high public profiles are more eager and better to present a positive social image through community (Khan, 2010). The disclosure of sustainability information serves to facilitate the projection of a socially accountable image (Michelon, 2011). Larger companies make more dan detail disclosures because they tend to attract more appreciation and attention from the authority and the general public (Kansal et al., 2014)

\subsection{CSR in Banking Industry}

Banks perform several responsible functions related their activities and their customers' groups and activities (Jain, R., \& Winner, 2016). Those activities must support both the customers and the bank performance. Therefore, to conform this, banks must integrate their social activities as part of their strategic planning and activities (Krasodomska, 2015). Theories about CSR in banking industry are often preceded by an understanding of the banking industry's stakeholders that involve either directly or not directly with the bank business; or parties affected or affecting business purposes of the bank (Khan, 2010). Stakeholders of banking industry are customers, employees, suppliers, community, government and stockholders (Jain, R., \& Winner, 2016). CSR is also defined as the company's efforts to meet its obligations to its stakeholders. Stakeholders of banking industry include internal and external, voluntary and involuntary, or primary and secondary. The dimensions of CSR are divided into the following ): a) Customer-oriented CSR which refers to complete and honest information about bank products and services, as well as the management of complaints; b). Shareholders and the board of supervisors-oriented CSR which refers to transparency and access to information on company profit; c).Employee-oriented CSR which refers to job creation, job opportunities; d) Society / 
community -oriented CSR which refers to donations, community development and environmental protection; Legal and ethicsoriented CSR which refer to legal and ethical issues (Pérez \& del Bosque, 2013).

\subsection{Sectors and Benefits of CSR}

Sectors of CSR compiled altogether by the researches of R.E Hinson (2011); Jain, Keneley, \& Thomson (2015); Kansal, Joshi, \& Batra (2014), Khan (201), Oobik, (2013) are formulated into several sectors that measure in assessing CSR in which that CSR has contributions. The sectors are of health, education sector, support the impact of natural disasters, other donations, activities for employees, social problems, products, services, and reports.

Researches of CSR have been well developed (Krasodomska, 2015). Several studies on CSR banking conducted in Polish, India, Bangladesh, China, Japan, America and Australia were about have been measured ethical standards, CSR Reporting, environment, products, community, employees, and supply chain (Jain et al., 2015). Another thing that a lot of CSR banks examined are related to the categories of the banks (Khan, 2010; Krasodomska, 2015; Laidroo \& Ööbik, 2014; Oobik, 2013, ). Several studies were conducted to establish banking CSR instrument (Kansal et al., 2014). While CSR research associated with certain characteristics of financial and non-financial as well as the acquisition of award have been studied by Hinson (2011); Kansal et al.(2014). Quite many CSR banking researches are related to the perception of consumers (Adegbola, 2015; Crosby, Evans, \& Cowles, 1990). CSR activities are not only activities that give donations, but it must also have an impact on positive things for the vendor in the short and medium term. That's why CSR design must be tailored to the company's strategic plan (Krasodomska, 2015). CSR program should not just be giving (philanthropy) but it must deliver impacts for the sustainability of the banks' business. The growth of the banking industry in Indonesian is considered good and if the banking CSR activities are aimed properly it will be a force to raise public awareness, to change the mindset of the people to perform better behavior, as well as to give impact for the sustainability of the banking business.

Meanwhile, based on the benefits of CSR, CSR activities in addition to types that are very diverse, the benefits also vary widely. However (Solihin, 2009) formulated that CSR has benefits that are beneficial for the company's internal and external environments as follows: 1) Philanthropy, 2) Promotion, 3) Business impact, 4) Mindset change. Philanthropy refer to any donation companies give away without considering of getting direct impact, such as helping the victims of natural disasters. Promotion refers to CSR activities that generally and widely help the strengthening and building image of the company. The impact for the business is not directly. Business Impact refers to the CSR impact that directly link to leverage the business performance of the company. Mindset change refers to the societal move of thought in line with their thinking change to improve life quality, such as giving up smoking, giving up drug, taking care better on rubbish and carbon usage, awareness of young generation on making investment rather than spending consumptively.

\section{DATA AND METHODOLOGY}

This research is a descriptive study that comprehensively characterize CSR activities of banks in Indonesian by analyzing the banks' annual reports focusing on their CSR reports. Descriptive research is research that describes a phenomenon with a specific purpose (Malhotra: 2010). The banks studied were conventional commercial banks especially banks categorized under $B U K U 3$ which means that the banks have capital range of 5-30 trillion. Sourced from Financial Services Authority, the number of the banks under this group is fifteen banks namely OCBC-NISP, Mizuho, BJB, Danamon,PTPN, Bukoppin, Panin, CIMB Niaga, BTN, Sumitomo Mitsui, Mega, Permata, Maybank, DBS, UOB. Based on these banks' official website, data were got, which were from each annual report in which CSR report is available. These 15 banks are under the category of Commercial Bank Business (BUKU 3) which further goes to their annual report of 30 September, 2015-108 issued by the Financial Service Authority (Otoritas Jasa Keuangan/ OJK). OJK is the government authority controlling and managing Indonesiann financial service organization including banks. The collection of secondary data was performed by content analysis method for observing the contents of the banks' Annual Report of 2015-2018. Further analysis techniques performed by descriptive statistics by doing the categorization of the entire CSR activities of banks based on its sectors formulated by Khan (2010), namely: 1) Environment, 2) Health sector, 2) Education sector, 3) Natural disasters, 4) Other donations, 5) Activities for employees, 6) bank products.

The second categorization is based on the CSR impacts that CSR has benefits that are beneficial for the company's internal and for external environments as follows: 1) Philanthropy, 2) Promotion, 3) Business impact, 4) Mindset change. The counting of CSR activities of each bank was done by counting the kind or type of activities. The example of counting is as follows, if a bank gives a scholarship to twenty students of Senior high School, 5 students of university, the reported or the counted number of CSR activity in education sector is two, not twenty five. Broadly speaking, the analysis stage is as follows: 


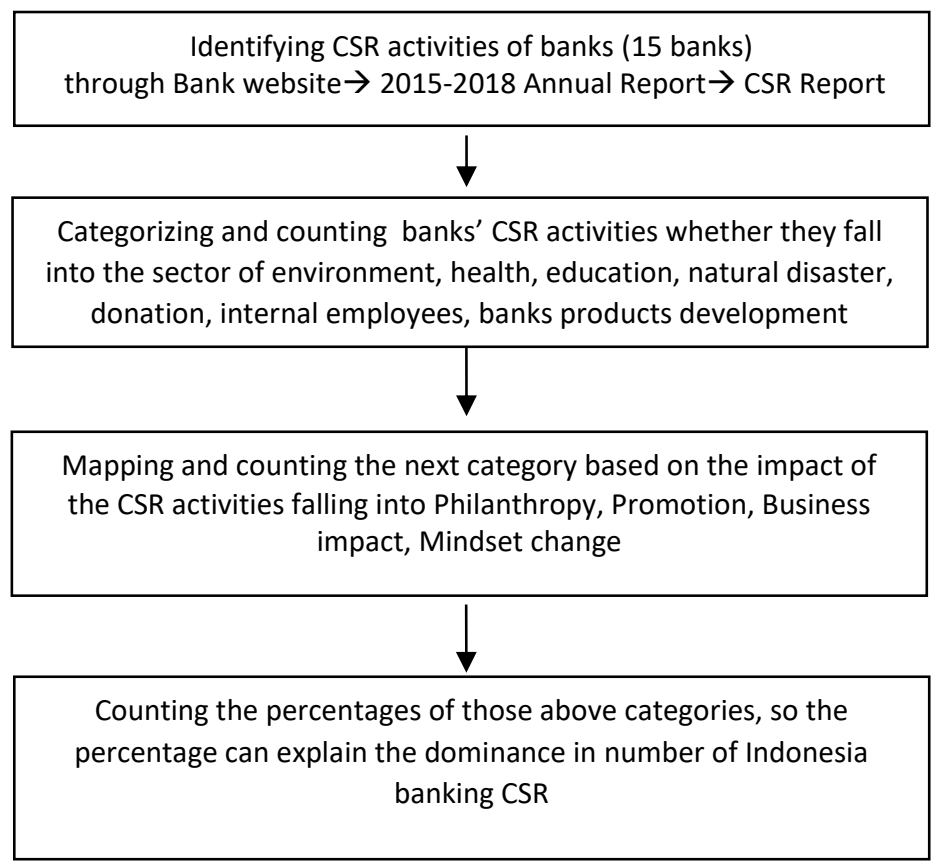

Figure 1

Stages of Content Analysis

\section{FINDINGS AND DISCUSSIONS}

Analysis on the CSR activities of banks that have been mapped by its category or sectors and its benefits reflects two areas which is the coverage of banks' strategy to sustain their business using CSR, and reflects the wider area which is condition of a country where the banks operate. The first area is evaluated so since the sectors that have been approached by the banks CSR tell how the banks have been considering and exposing themselves in the fields that strategically show their intention. The second area reflects the condition of a country since the benefit or impact of CSR might tell the level of community quality since the usefulness of the lowest CSR is philanthropy and the highest is the changing the mindset / mindset of the people. Thus, the analysis of the substance of the CSR depicts those two big areas. Along with these stages also emphasized that CSR should also support the sustainability of the company's business, because the company's business sustainability also means CSR sustainability. The results of the analysis of CSR programs of Indonesiann banks involving 15 banks under the category of Commercial Bank Business Group (BUKU 3: Bank Umum Kelompok Usaha 3) which further goes to their annual report of 30 September, 2015-2018 issued by the Financial Service Authority which is the government authority controlling and manage Indonesian financial service organization including banks.

The result of the analysis is based on two categories which are the sectors of CSR group and the impact or benefit of CSR. CSR activities are categorized based on its sectors/ category as follows: 1) Environment, 2) Health, 3) Education, 4) Disaster Assistance, 5) Donation, 6) Internal Interests (Bank Employees), 7) Banking Products. While the second categorization of banks CSR is based on the impacts or benefit of the bank's CSR programs as follows:1) Philanthropy (donation), 2) Promotion, 3) Business Impact (impact on the banking business), which is more specific than Promotion, 4) Mindset change (change of community mindset). The results of the identification is presented in Appendix 1.

Based on the above identification of CSR activities by its sectors, education takes the highest portion namely $26 \%$, followed by environment $22 \%$, employees $20 \%$, donation $12 \%$ and health $11 \%$. The least portion goes to disaster fictims assistance, bank product development and other which are the same percentage of $3 \%$. The sectors that have been approached by the banks CSR explain how the banks have been considering and exposing themselves in the fields that strategically show their intention. For example, OCBC bank concerns a lot on helping to conserve environment (14 kinds of CSR programs on environment) and to supporting their employees development ( 23 kinds of CSR programs on environment). The data also helps to evaluate which banks having more CSR activities. Based on the data it is known that the banks having more varied CSR programs are OCBC-NISP, 
Maybank, Bukopin, and BTN. Anyhow this ranking does not refer to the number of spending financially, since the lack of the analysis is that only a few number of the bank annual report that report id detail the money spent for each sector of CSR.

Looking into the impacts of CSR, the result shows that similar rank to the sector referring relatively the same banks which are OCBC-NISP, Bukopin, Maybank by giving different two banks in the rank namely BTN (better rank in term of CSR sector, and CIMB Niaga (better in term of CSR impacts). These four banks showing good rank in impact showed that they had good level for their CSR holding promotion impact and business impact. So, in the future, these banks may be predicted to have better image and stronger business sustainability. Anyhow if the identification of the CSR program are summed into a percentage, the result can be seen in graph 1 and graph 2 .

Graph 1

CSR Implementation by Sectors

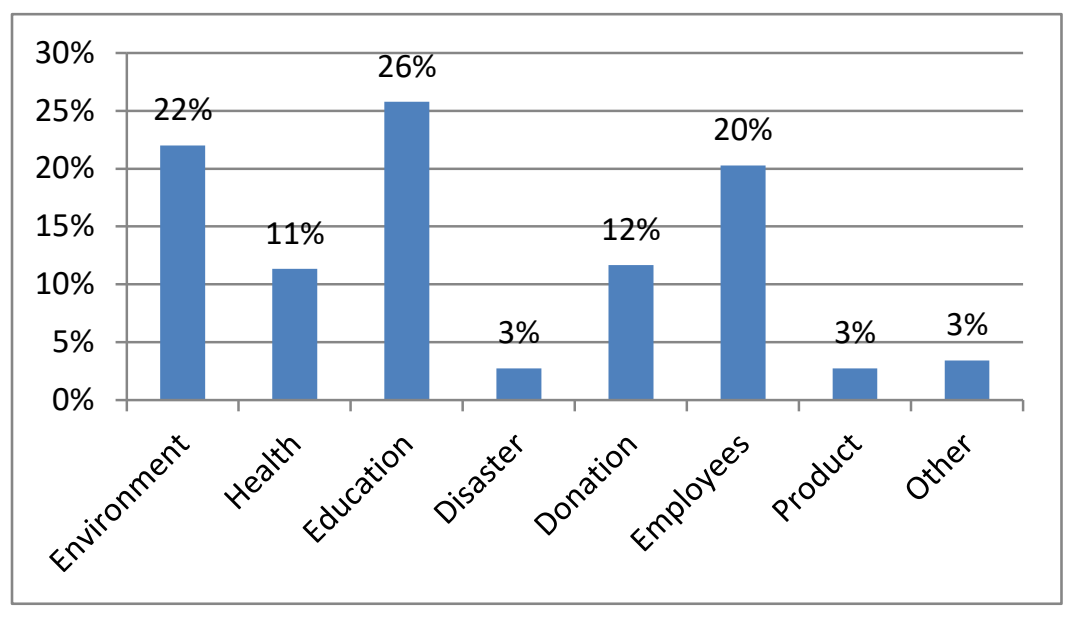

Source: Banks' Annual Report of 2015-2018 (Analyzed)

From the CSR program category it appears that education sector dominates the CSR coverage (26\%), environment (22\%), employees (20\%) and donations (12\%). CSR is not only activities caring people outside companies but also for internal employees to help develop them that in turn also benefit for the company and business sustainability.

Graph 2

CSR Implementation by Impacts

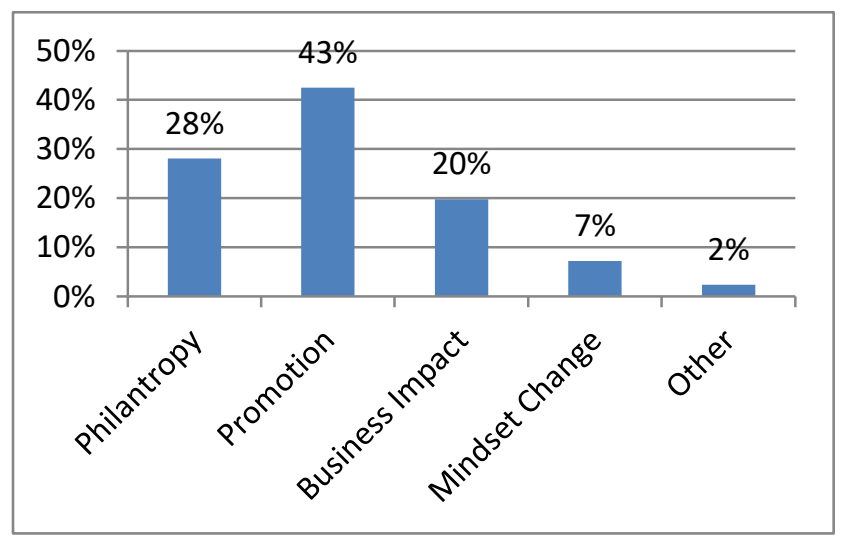

Source: Banks' Annual Report of 2015-2018 (Analyzed) 
With the dominance designation of $20 \%$ of employees can be assessed that the bank has been good in allocating funds to develop their employees. This also shows that nationally, banking industry shows a balanced CSR programs that is not only for external but also for internal parties. Employees have the strength to support the sustainability of the bank's business. In the perspective of strategic management, the long-term strategic plan the company must consider aspects relating to employees in the form of employee development in the form of trainings and employee relations in the form of working conditions and employee welfare. In this case CSR study includes CSR activities, which it must take precede before the implementation of CSR to external parties.

In terms of the usefulness or impacts of CSR (CSR Benefits), it appears that CSR programs are charged Promotion Bank amounting to $43 \%$, while charity $(28 \%)$, which leads to a specific bank business impact $20 \%$. However, the impact on the mindset change is still very small at only $7 \%$. It can be interpreted that the banks in the developing country like Indonesian, the tendency of CSR implementation take this pattern because the banks will tend to help poor community groups, while from the perspective of CSR study, CSR impacting highest value is when it benefits to the change of mindset of the communities where it contributes to the quality and competitiveness of human beings. While the impact of promotion and business impact is the sustainability of the banking industry in the future.

\section{CONCLUSION}

The aims of this study are to evaluate and analyze the implementation of Corporate Social Responsibility (CSR) programs in Indonesiann banking industry. CSR benefits having been implemented for bank stakeholders should contribute to the bank's business continuity. The research result is presented by CSR sector and by CSR impacts. Thus, the research having been descriptively analyzied can be concluded based on these two categories. By CSR sectors, the basis sectors determined in banking industry are: 1) Environment, 2) Health, 3) Education, 4) Disaster Assistance, 5) Donation, 6) Internal Interests (Bank Employees), 7) Banking Products. The result showed that the high coverage sectors are successively education sector, environment, employees and donations. Indonesian banking industry has shown balanced sector of CSR implementation which was implemented for external parties and internal ones (employees). The banks having good rank in term of the kind/ variety of CSR sectors are relatively also have good rank in term of CSR impacts.

By impacts theoretically falling into four levels namely 1) Philanthropy (donation), 2) Promotion, 3) Business Impact (which is more specific than Promotion), 4) Mindset change. Banks having good rank in CSR impacts showed good level in CSR impact of promotion and business impact. By CSR impacts, Indonesian banking industry has shown good level to be aware of promoting and caring for business impacts for the bank business sustainability. Indonesian banking industry show very weak role in helping people change their mind set for gaining better human behavior.

Banks having good CSR impact level, which are mostly mix-bank (owned by domestic and foreign owners) have good point in CSR promotion impact and business impact. Good point in these two impacts means that it can be predicted that these banks have potential power for their sustainability. This is because they have started to have good efforts which are promotion and activities triggering people to be always aware of the banks' existence. 


\section{REFERENCES}

Adegbola, E. A. (2015). Corporate Social Responsibility as a Marketing Strategy for Enhanced Performance in the Nigerian Banking Industry: A Granger Causality Approach. Procedia - Social and Behavioral Sciences, 164(August), 141-149. https://doi.org/10.1016/j.sbspro.2014.11.062

Chaudhri, V. (2016). Corporate social responsibility and the communication imperative: Perspectives from CSR managers. International Journal of Business Communication, 53(4), 419-442. https://doi.org/10.1177/2329488414525469

Crosby, L. a., Evans, K. R., \& Cowles, D. (1990). Relationship Quality in Services Selling: An Interpersonal Influence Perspective. Journal of Marketing, 54(3), 68. https://doi.org/10.2307/1251817

Gao, Y. (2011). CSR in an emerging country: A content analysis of CSR reports of listed companies. Baltic Journal of Management, 6(2), $263-291$. https://doi.org/10.1108/17465261111131848

Garriga, E., \& Mele, D. (2004). Corporate Social Responsibility Theories: Mapping the. Journal of Business Ethics, 53, 51-71.

Hinson, R. . (2011). Journal of Information , Communication and Ethics in Society Article information: 9(2), 102-115. https://doi.org/10.1108/14779961111148622

Jain, R., \& Winner, L. H. (2016). CSR and sustainability reporting practices of top companies in India. Corporate Communications: An International Journal, 21(1), 36-55.

Jain, A., Keneley, M., \& Thomson, D. (2015). Voluntary CSR disclosure works ! Evidence from Asia - Pacific banks.

Kansal, M., Joshi, M., \& Batra, G. S. (2014). Determinants of corporate social responsibility disclosures: Evidence from India. Advances in Accounting, 30(1), 217-229. https://doi.org/10.1016/j.adiac.2014.03.009

Khan, H. U. Z. (2010). The effect of corporate governance elements on corporate social responsibility (CSR); reporting: Empirical evidence from private commercial banks of Bangladesh. International Journal of Law and Management, 52(2), 82-109. https://doi.org/10.1108/17542431011029406

Krasodomska, J. (2015). CSR disclosures in the banking industry, Empirical evidence from Poland. Social Responsibility Journal, 11(3), 406-423. https://doi.org/10.1108/SRJ-02-2013-0019

Laidroo, L., \& Ööbik, U. (2014). Banks' CSR disclosures - headquarters versus subsidiaries. Baltic Journal of Management, 9(1), 47-70. https://doi.org/10.1108/BJM-05-2013-0091

Michelon, G. (2011). Sustainability disclosure and reputation: A comparative study. Corporate Reputation Review, 14(2), 79-96. https://doi.org/10.1057/crr.2011.10

Oobik, L. L. U. (2013). Banks' CSR disclosures - headquarters versus subsidiaries. 9(1), 47-70. https://doi.org/10.1108/BJM-05-2013-0091

Pérez, A., \& del Bosque, I. R. (2013). Extending on the formation process of CSR image. Social Marketing Quarterly, 19(3), $156-171$. https://doi.org/10.1177/1524500413489287

Pérez, A., \& Del Bosque, I. R. (2015). The formation of customer csr perceptions in the banking sector: The role of coherence, altruism, expertise and trustworthiness. International Journal of Business and Society, 16(1), 75-94.

Pérez, A., \& Lopez-Gutierrez, C. (2017). An empirical analysis of the relationship between the information quality of CSR reporting and reputation among publicly traded companies in Spain. Academia Revista Latinoamericana de Administración, 30(1), 87-107. https://doi.org/10.1108/ARLA-02-2016-0036

Solihin. (2009). Corporate Social responsibility: From Charity to Sustainability.

Virvilaite, R., \& Daubaraite, U. (2011). Corporate Social Responsibility in Forming Corporate Image. Engineering Economics, 22(5), 534-543. https://doi.org/10.5755/j01.ee.22.5.972

Wilburn, K., \& Wilburn, R. (2013). Using Global Reporting Initiative indicators for CSR programs. Journal of Global Responsibility, 4(1), 62-75. https://doi.org/10.1108/20412561311324078

Yeo, R. K., \& Youssef, M. A. (2010). Communicating corporate image into existence: The case of the Saudi banking industry. Corporate Communications, 15(3), 263-280. https://doi.org/10.1108/13563281011068122 
Appendix 1

The Result of CSR Identification by Sectors and Impact

\begin{tabular}{|c|c|c|c|c|c|c|c|c|c|c|c|c|c|c|c|c|}
\hline \multicolumn{11}{|c|}{ CSR Program Identification by Sectors } & \multicolumn{6}{|c|}{ CSR Program Identification by Impacts } \\
\hline No & Banks & $\begin{array}{c}\text { Environ } \\
\text { ment }\end{array}$ & Health & $\begin{array}{c}\text { Edu } \\
\text { cation }\end{array}$ & Disaster & Donation & Employees & Product & Other & Total & Philantropy & Promotion & $\begin{array}{l}\text { Business } \\
\text { Impact }\end{array}$ & $\begin{array}{l}\text { Mindset } \\
\text { Change }\end{array}$ & Other & Total \\
\hline 1 & OCBC & 14 & 3 & 9 & 0 & 4 & 23 & 5 & 1 & 59 & 15 & 15 & 26 & 12 & 8 & 76 \\
\hline 2 & MIZUHO & 4 & 1 & 0 & 0 & 0 & 0 & 0 & 0 & 5 & 3 & 4 & 0 & 1 & 0 & 8 \\
\hline 3 & BJB BANK & 1 & 6 & 0 & 2 & 3 & 0 & 0 & 0 & 12 & 10 & 10 & 0 & 0 & 0 & 20 \\
\hline 4 & DANAMON & 11 & 1 & 0 & 1 & 1 & 0 & 0 & 1 & 15 & 3 & 4 & 0 & 0 & 0 & 7 \\
\hline 5 & BTPN & 0 & 1 & 5 & 0 & 0 & 0 & 0 & 0 & 6 & 0 & 6 & 0 & 0 & 0 & 6 \\
\hline 6 & BUKOPIN & 7 & 3 & 6 & 2 & 6 & 14 & 3 & 0 & 41 & 14 & 14 & 24 & 2 & 0 & 54 \\
\hline \multirow[t]{2}{*}{7} & PANIN & 3 & 1 & 1 & 0 & 0 & 0 & 0 & 0 & 5 & 3 & 3 & 0 & 0 & 0 & 6 \\
\hline & CIMB & & & & & & & & & & & & & & & \\
\hline 8 & NIAGA & 3 & 2 & 11 & 0 & 0 & 3 & 0 & 0 & 19 & 10 & 17 & 2 & 0 & 1 & 30 \\
\hline 9 & BTN & 9 & 8 & 4 & 1 & 1 & 5 & 0 & 2 & 30 & 3 & 7 & 0 & 0 & 0 & 10 \\
\hline 10 & $\begin{array}{l}\text { SUMITOMO } \\
\text { MITSUI }\end{array}$ & 0 & 0 & 3 & 0 & 0 & 0 & 0 & 0 & 3 & 2 & 3 & 0 & 0 & 0 & 5 \\
\hline 11 & MEGA & 0 & 2 & 4 & 1 & 4 & 0 & 0 & 0 & 11 & 6 & 11 & 1 & 3 & 0 & 21 \\
\hline 12 & PERMATA & 0 & 0 & 11 & 0 & 0 & 0 & 0 & 0 & 11 & 11 & 11 & 0 & 0 & 0 & 22 \\
\hline 13 & MAYBANK & 10 & 3 & 6 & 1 & 12 & 14 & 0 & 6 & 52 & 21 & 33 & 20 & 5 & 0 & 79 \\
\hline 14 & DBS & 1 & 0 & 13 & 0 & 0 & 0 & 0 & 0 & 14 & 1 & 14 & 1 & 2 & 0 & 18 \\
\hline \multirow[t]{3}{*}{15} & UOB & 1 & 2 & 2 & 0 & 3 & 0 & 0 & 0 & 8 & 3 & 7 & 0 & 2 & 0 & 12 \\
\hline & TOTAL & 64 & 33 & 75 & 8 & 34 & 59 & 8 & 10 & 291 & 105 & 159 & 74 & 27 & 9 & 374 \\
\hline & & $22 \%$ & $11 \%$ & $26 \%$ & $3 \%$ & $12 \%$ & $20 \%$ & $3 \%$ & $3 \%$ & $100 \%$ & $28 \%$ & $43 \%$ & $20 \%$ & $7 \%$ & $2 \%$ & $100 \%$ \\
\hline
\end{tabular}

